\title{
SEIS VERSOS PARA JULIÁN MEZA
}

Ya habrás visitado París, las islas griegas, las siete colinas de Constantino el Grande. Siempre quisiste pasar la vida viajando. Los cementerios etruscos eran más amplios más hermosos que sus aldeas para los vivos. No es necesario explicar esa metáfora.

\section{Cuaderno de AVES}

Dicen que Hokusai compraba pájaros para liberarlos.

JosÉ WATANABE

1.

Es una falsedad muy extendida que los animales carezcan de sentido estético. No somos los únicos que volvemos de viaje con objetos que sostienen un recuerdo incapaz de sujetarse por sí mismo. Los pájaros arquitectos, que viven al norte de Australia y en Nueva Guinea, construyen círculos de tierra y chozas pequeñas en las que acumulan objetos para atraer a la hembra: varitas, corcholatas, piedras, monedas, pedazos de vidrio o de hueso. Hacen túneles, extienden muros de ramas, juntan todo por colores y pintan las ramitas con bayas y carbón húmedo. Prefieren lo que brilla. A veces el ritual de apareamiento falla y la casa se derrumba, pero no importa: siempre puede reconstruirse y nadie tiene que preocuparse por lo que pasará con estos objetos cuando falten sus dueños ni pensar a donde irán a parar cuando llegue la hora de hacer el inventario. 
Me gusta más la palabra ave que la palaba pájaro: con ave me imagino al animal en el aire y con pájaro lo pienso quieto en la rama de un árbol o recogiendo con el pico las migajas del pavimento. Ave es una palabra de aire, pájaro de tierra.

Pájaro, del latín passar, significa gorrión: la familia de los paseriformes, la orden de aves que abarca a más de la mitad de sus especies, son "los que tienen forma de gorrión”. Entonces todos los pájaros son aves, pero no todas las aves son pájaros. Las gallinas, por ejemplo. Lo contrario a lo que yo pensaba: para mí una gallina es más un pájaro que un ave, porque pasa casi todo el tiempo al ras del piso. Pero debo aceptar que sería raro llamar pájaro a un avestruz, a un pingüino o a un cóndor. Tengo un amigo que le tiene miedo a las aves. No miedo, terror: ornitofobia. Les huye a las palomas en las plazas públicas, evita el pasillo de los pollos en los mercados y sueña con frecuencia que una parvada se estampa contra la ventana de su cuarto y todas las aves terminan muertas en el alféizar. Le da asco la palabra "rabadilla".

No sabe exactamente de dónde viene su fobia y tampoco le interesa demasiado averiguarlo. Una vez, de niño, un guajolote confundió sus ojos con granos de maíz en el rancho de una tía. Unos años después, casi se desmaya cuando un buitre abrió sus alas gigantescas frente a él en un aviario. O quizá es simplemente que era demasiado pequeño cuando vio la película de Hitchcock. Nunca se lo he preguntado, pero casi podría asegurar que él prefiere la palabra pájaro. 


\section{3.}

Flaubert tuvo un loro disecado sobre su mesa durante las tres semanas que escribió "Un corazón sencillo". El fantasma emplumado le servía, según le cuenta a Madame Brainne en una carta, para llenarse el cerebro con la idea del loro mientras imaginaba la historia de Félicité, la sirvienta normanda a la que el pájaro le dio los pocos momentos dichosos de su vida. El animal sobrevive por duplicado: un ejemplar está en el Museo de Historia de la Medicina de Ruan, en el hospital donde alguna vez ejerció el padre de Flaubert, y el otro en su casa familiar en Croisset. Ambos sitos afirman tener pruebas escritas de ser poseedores del verdadero loro. Los dos tienen la idea del loro y está bien: a fin de cuentas, todo es copia de otra cosa.

Se puede migrar en espacios pequeños. Por ejemplo, en una casa. Dice Natalia Ginzburg:

Hay algo de lo que no nos curamos, y pasarán los años y no nos curaremos nunca. Quizá tengamos una lámpara sobre la mesa y un jarrón con flores y los retratos de nuestros seres queridos, pero ya no creemos en ninguna de esas cosas, porque una vez tuvimos que abandonarlas de repente o las buscamos inútilmente entre los escombros.

Todos hemos buscado la casa inútilmente entre los escombros.

Los días previos a su muerte, mi padre soñaba que había alacranes en su cuarto. Pasó su penúltima 
noche en vela, despertando a mi hermana a cada rato para decirle que caían alacranes del techo, que subían por las patas de su cama, que por favor se levantara a ayudarle a matar alacranes. Hablaba haciendo señas con las manos, descolocado, como traduciéndose de un idioma que venía de lejos. La casa se rompe, se construye y se vuelve a romper. Pero algo se conserva siempre, espacios que rebasan su territorio, posesiones que no es necesario meter en cajas ni rescatar del derrumbe porque son imposibles de perder. Paredes que no se desbaratan porque su estabilidad es de otra índole. Nueva definición de hogar: algo que se (re)construye todos los días. ¿Otra manera de migrar?

\section{5.}

El artista Jimmie Durham se sorprendió al ver cuervos blancos cuando visitó Roma por primera vez. En su mundo, todos los cuervos eran negros. Cuando un ornitólogo le explicó que los cuervos del Oeste son negros y los del Este pueden ser blancos o grises, Durham, que había estado pensando en la división entre Asia y Europa, encontró en aquella clasificación la respuesta a sus cavilaciones. A los continentes no los determinaban sus estructuras sociales ni su producción cultural, la división no estaba marcada por montañas, ríos, fallas geológicas. La frontera eran los cuervos. Tal vez el mundo entero pueda conocerse por sus pájaros. Habría que alzar la vista y mantenerla en constante movimiento para aprender a mirar los vuelos. 
Se prohíbe su reproducción total o parcial por cualquier medio, incluido electrónico, sin permiso previo y por escrito de los editores. 